\title{
PREVALENCE OF PARASITES WITH ZOONOTIC POTENTIAL IN SOIL FROM THE MAIN PUBLIC PARKS AND SQUARES IN CAXIAS DO SUL, RS, BRAZIL
}

\author{
Jewers Matheus Bortolatto ${ }^{1}$, Marcella Maris Sniegovskil, Stela Teixeira \\ Bernardi ${ }^{1}$, Liziane Bertotti Crippa ${ }^{1}$ and Adriana Dalpicolli Rodrigues ${ }^{2}$
}

\begin{abstract}
Soil contamination in parks and public squares caused by animal feces has been one of the main forms of parasitic contamination, becoming therefore a public health problem. The purpose of this study was to determine the prevalence of parasites in the soil in major parks and public squares in Caxias do Sul, RS, Brazil. Two samplings were performed at each location, the first in summer (February) and the second in winter (July) in 2015. Soil samples were collected in five spots in ten parks/public squares, per season and examined using the Hoffman, Pons \& Janer (HPJ), Faust and Rugai, Mattos and Brisola methods. Among the 100 samples analyzed by HPJ and Rugai, Mattos and Brisola, $64 \%$ and $58 \%$ respectively, proved positive in summer and $28 \%$ and $60 \%$ in winter. The Faust method showed the same number of positive samples in both seasons (12\% each). The following parasites were found: Cystosospora sp oocysts (4\%), Entamoeba coli cysts (1\%), Strongyloides stercoralis suggestive larvae (0.3\%), Endolimax nana cysts (1\%) and Ancylostoma sp suggestive larvae (33.3\%) with the highest prevalence. Both parks and squares presented parasites with zoonotic potential. Thus, it is necessary to highlight the importance of educational measures regarding the use of these locations as well as the cleaning of public areas with the removal of animal excrements.
\end{abstract}

KEY WORDS: Parasites; enteroparasites; public health; environment.

\section{INTRODUCTION}

The natural environment and mankind have been mutually attracted since earliest times. To survive, humans have always needed natural resources (Santin, 1993), and proof of this is in the increasing number of individuals who have practiced physical activities outdoors in recent years (Albino et al., 2010) in parks and public squares which are ideal for this kind of activity (Silveira \& Silva, 2010). Physical exercise is a form of entertainment and is beneficial in reducing the adverse effects of stress from work, helping to improve self-esteem (Silveira \& Silva, 2010).

\footnotetext{
1. Centro Universitário da Serra Gaúcha, Caxias do Sul, Rio Grande do Sul, Brazil.

2. Centro Universitário de Tecnologia (Uniftec), Caxias do Sul, Rio Grande do Sul, Brazil.

Corresponding author: E-mail: adry.dr@gmail.com

Received for publication: 12/6/2016. Reviewed: 17/3/2017. Accepted: 20/3/2017.
} 
While physical activity is beneficial for the health of human beings, it can contribute to the development and spread of zoonotic diseases, given that individuals do not always take the necessary precautions to avoid exposure to microorganisms, such as skin contact with parasite contaminated soil. Poor environmental conditions and housing added to lack of hygiene, inadequate sanitation and basic levels of education, are some of the main factors contributing to the transmission of parasitic infections (Robertson et al., 2000; Anaruma, 2002; Traub et al., 2004; Pastório et al., 2009).

It is known that both dogs and cats, domestic or not, may defecate on streets, making these places a major focus for zoonosis transmission (Capuano $\&$ Rocha, 2005). This happens mainly because many owners are careless about collecting feces and the collection of this material by the public service may not be immediate. There are many organisms that parasitize these animals and when parasitic structures, such as cysts, oocysts, eggs and larvae are excreted in feces and dropped on the soil, they can infect a new host, be it animal or human (Pastório et al., 2009). Among the species that parasitize these animals, the most common are Toxocara canis or Toxocara catis, Ancylostoma sp, Trichuris vulpis or Trichuris campanula and Giardia lamblia. Toxocara sp and Ancylostoma sp etiological agents of visceral and cutaneous Larva migrans (Schantz, 1991; Robertson et al., 2000; Dunn et al., 2002).

Estimates show that parasites affect around 3.5 billion people worldwide, causing diseases in approximately 450 million. Children are the most affected (WHO, 2008; Neves et al., 2012) as their recreational activities are often directly linked to soil and sand, and because they are more in contact with animals. Children also often present disorders like geophagia and onycophagia, habits which favor the intake of eggs and/or cysts of various parasites contained in the soil (Glickman \& Schantz, 1981; Capuano \& Rocha, 2006; Chiodo, 2006; Motazedian et al., 2006; Gawor, 2008). Parasites may cause various physical disturbances to their hosts, such as inflammations, nutritional, neurological and cognitive problems, bleeding, difficulty in defecating and rectal prolapse. They may also affect fetal development, leading to physical and mental retardation, and even be the cause of death (Pessoa \& Martins, 1978; Santos \& Merlini, 2010).

Many government programs have been implemented in several countries in order to control these diseases caused by intestinal parasites. However, in developing countries, these initiatives are not very effective due to insufficient financial support for adequate sanitation, and the lack of participation of the population itself (WHO, 1987; Pedrazzani et al., 1989).

The purpose of this study was, therefore, to evaluate the prevalence of soil and sand contamination by parasitic structures from worms and protozoa in public parks and squares in Caxias do Sul, RS. Furthermore, a comparative study was performed on the prevalence of parasites within the period of one month in summer and one month in winter. 


\section{MATERIAL AND METHODS}

To assess the prevalence of soil contamination by worms and protozoa, during February (summer) and July (winter) 2015, soil and sand sampling were performed in the Monteiro Lobato, Bandeira, Presidente Joao Pessoa and Dante Alighieri squares, in the Getulio Vargas, Cinquentenário and Lagoa parks, in the playgrounds around the Cinquantenário and Madureira neighborhoods and in the Botanical Gardens. These squares and parks are located in Caxias do Sul, Rio Grande do Sul, Brazil, and were chosen because they are frequently used by people for leisure and outdoor activities.

From each square and park (totaling 10 places), five soil samples were collected in the summer and five in the winter using gardening shovels. Each sample consisted of approximately $100 \mathrm{~g}$ of soil and was collected at a depth of about $10 \mathrm{~cm}$. The samples were placed in sterile plastic bags, labeled and kept in a cool box for transportation. The samples were analyzed in the Parasitology Laboratory of the Faculdade da Serra Gaúcha, in Caxias do Sul, RS, following the Hoffman, Pons and Janer (HPJ), Faust, and Rugai, Mattos and Brisola methods (De Carli, 2007). These methodologies were chosen due to the possibility of identifying specific types of parasites. The HPJ method is regularly used in laboratories and is based on spontaneous sedimentation, contributing to the visualization of helminth eggs/larvae and protozoan oocysts. The Faust method is used to verify the existence of cysts and oocysts from protozoa by centrifugal flotation in zinc sulfate, and the Rugai, Mattos and Brisola method is based on positive hydrotropism of nematode larvae (De Carli, 2007). In addition, these techniques are not expensive and are easily applied.

The samples were stained in duplicate using Lugol, covered with coverslips and observed under optical microscopy at 10x and 40x by two microscopists. This study was evaluated qualitatively, so every sample presenting at least one parasitic structure was considered positive, highlighting the evolutionary stage and the identification of the parasite.

Data were processed in the Statistical Package for Social Sciences (SPSS) version 19.0. The data, being categorical, were expressed in absolute frequencies and values. Station chi-square test was used for comparative analyzes, where a $5 \%$ significance level was adopted for statistical difference.

\section{RESULTS}

According to Table 1, within a total of 100 samples analyzed (50 per season) following the HPJ method in the first sampling (in summer), $64 \%$ ( $\mathrm{n}=$ 32 ) were positive, while in the second sampling (in winter) $28 \%$ of the samples were positive $(\mathrm{n}=14)$. According to the analysis performed using the Faust method, in the first and second samplings, $12 \%(\mathrm{n}=6)$ of the samples were 
positive for each sampling. In the analysis performed with the Rugai, Mattos and Brisola method, in the first sampling $58 \%(\mathrm{n}=29)$ of the samples were positive and $60 \%(n=30)$ in the second sampling. No statistical difference was observed comparing the samples per season of the year.

Table 1. Positive soil samples for parasites collected in February and July 2015 in public squares and parks in Caxias do Sul, RS, Brazil.

\begin{tabular}{ccc}
\hline Method & 1st sampling $(\mathrm{n}=50)$ & 2nd sampling $(\mathrm{n}=50)$ \\
& February & July \\
\hline Hoffman, Pons \& Janer & $32(64 \%)$ & $14(28 \%)$ \\
Faust & $6(12 \%)$ & $6(12 \%)$ \\
Rugai, Mattos \& Brisola & $29(58 \%)$ & $30(60 \%)$ \\
\hline
\end{tabular}

Table 2 shows the presence of two or more parasitic structures in the samples. It is possible to notice that $60 \%(n=6)$ of the squares/parks presented polyparasitism in the first sampling analyzed with HPJ method, although in the second sampling this percentage decreased to $30 \%(n=3)$. In relation to the Faust method, there was no presence of polyparasitism for the first sampling, and only $10 \%(\mathrm{n}=1)$ of the squares presented polyparasitism in the second sampling. For those samples analyzed using the Rugai, Mattos and Brisola method, neither of the samplings presented polyparasitism.

Table 2. Prevalence of polyparasitism in the samples collected in February and July 2015 in public squares and parks in Caxias do Sul, RS, Brazil.

\begin{tabular}{ccc}
\hline Method & 1st sampling $(\mathrm{n}=50)$ & 2nd sampling $(\mathrm{n}=50)$ \\
\hline Hoffman, Pons \& Janer & $6(60 \%)$ & $3(30 \%)$ \\
Faust & - & $1(10 \%)$ \\
Rugai, Mattos \& Brisola & - & - \\
\hline
\end{tabular}

Among the 300 analyses (100 samples per method) shown in Table 3 , in $61 \%(n=183)$ parasitic structures were not observed. In $39 \%(n=117)$ of the positive samples, $33.3 \%(\mathrm{n}=100)$ contained the presence of larvae suggestive of Ancylostomidea, 4\% $(\mathrm{n}=12)$ Cystosospora sp oocysts, $1 \%(\mathrm{n}=3)$ Entamoeba coli cysts, $0.3 \%(\mathrm{n}=1)$ larvae suggestive of Strongyloides $s p$ and $0.3 \%(\mathrm{n}=1)$ Endolimax nana cysts. 
Table 3. Prevalence of parasites in soil from public squares and parks in Caxias do Sul, RS, Brazil in 2015, adding positivity to all methods performed.

\begin{tabular}{ccc}
\hline Result & N & $\%$ \\
\hline Negative & 183 & 61 \\
Suggestive of Ancylostoma sp larvae & 100 & 33.3 \\
Cystosospora sp oocysts & 12 & 4 \\
Entamoeba coli cysts & 3 & 1 \\
Suggestive of Strongyloides sp & 1 & 0.3 \\
larvae & 1 & 0.3 \\
Endolimax nana cysts & 300 & 100 \\
Total number of analyses & &
\end{tabular}

After 300 analyses, this study detected that all the parks and squares were contaminated by some form of parasitic structure. Table 4 shows the frequency of positivity for each square/park along with the species found. The most parasitized place was João Pessoa Square, with a positivity of 5.3\%, while Lagoa Park was the least parasitized site, with a positivity of $2.6 \%$.

Table 4. Frequency of positivity (\%) for isolated parasites in soil/sand from public squares and parks in Caxias do Sul, RS, in February and July 2015, adding positivity to all methods performed ( $\mathrm{n}=300$ analyses).

\begin{tabular}{lccccc}
\hline \multicolumn{1}{c}{ Sampling sites } & \multicolumn{2}{c}{ Larvae (suggestive) } & \multicolumn{2}{c}{ Cysts } & Oocysts \\
& $\begin{array}{c}\text { Ancylostoma } \\
\text { sp }\end{array}$ & $\begin{array}{c}\text { Strongyloides } \\
\mathrm{sp}\end{array}$ & $\begin{array}{c}\text { Entamoeba } \\
\text { coli }\end{array}$ & $\begin{array}{c}\text { Endolimax } \\
\text { nana }\end{array}$ & $\begin{array}{c}\text { Cystosospora } \\
\text { sp }\end{array}$ \\
\hline Squares & & & & & - \\
Bandeira & 3 & - & 0.3 & - & - \\
João Pessoa & 4 & - & 0.3 & 0.3 & 0.7 \\
Monteiro Lobato & 2.7 & - & 0.3 & - & 1.7 \\
Dante Alighieri & 3.3 & - & - & - & - \\
Parks & & & - & - & - \\
Getúlio Vargas & 4 & 0.3 & - & - & - \\
Cinquentenário & 4.3 & - & - & - & 0.3 \\
Lagoa & 2.3 & - & - & - & 0.3 \\
Jardim Botânico & 3 & - & - & - & 0.3 \\
Parquinho & 3.3 & - & - & - & 0.7 \\
Cinquentenário & & - & - & - & \\
Parquinho & 3.3 & & & &
\end{tabular}




\section{DISCUSSION}

This study demonstrated that all analyzed parks and squares were potential transmitters of parasites to individuals who use them for any recreational purposes. Among the parks and squares analyzed, 39\% were contaminated by at least one parasitic stage. Among the positive samples the following parasitic structures were identified: larvae suggestive of Ancylostoma $\mathrm{sp}$ and of Strongyloides sp, Cystosospora sp oocysts, Entamoeba coli and Endolimax nana cysts. In studies carried out in the southern region of Brazil $52 \%$ parasitic structures were observed by Mascarenhas and da Silva (2016) in soil from recreation areas in schools and 40\% by Pritsch and Frighetto (2016) in public squares. Ancylostoma sp was the only worm in common with ours in both studies.

The highest prevalence noted was the genus Ancylostoma sp (33.3\%), corroborating the study conducted by Miranda et al. (2015), where the presence of this parasite was observed in all samples, and Nunes et al. (2000), who after analyzing sand samples from recreational areas from schools in Araçatuba, SP, Brazil, through the centrifugal flotation and Baermann methods, verified the presence $46.4 \%$ of this kind of larvae. Scaini et al. (2003) analyzed 237 samples of soil in the city of Balneario Casino, RS in 2002, using Willis flotation method, and found 169 (71.3\%) positive samples for Ancylostoma sp. In a study carried out by Ribeiro et al. (2013), a frequency of $85 \%$ was found for these larvae in squares in the city of Belo Horizonte, using Caldwell \& Caldwell and HPJ methods.

According to Labruna et al. (2006) the genus Ancylostoma is the most common in dogs and cats, confirming the high prevalence of positive samples in our study, as the number of these animals in public areas is high. Coelho et al. (2011) found Ancylostoma sp eggs in $87.8 \%$ of the fecal samples collected from dogs and in $94.2 \%$ of the fecal samples collected from cats using the WillisMollay method in Andradina, São Paulo.

This helminth, which is the etiologic agent for cutaneous Larva migrans, is mainly transmitted through active penetration into the skin by direct contact of individuals with contaminated soil, usually through the hands or feet. This confirms the high probability of contamination in public areas (Neves \& Massara, 2009; Pastório et al., 2009).

Concerning the methods used, after analyzing all the samples, the Rugai, Mattos Brisola and HPJ methods were found to be the most effective because of the number of positive samples for Ancylostoma sp larvae. In the samples analyzed using the Faust method, the positive percentage was lower. This is probably due to the low prevalence of protozoa in the samples, or to the low specificity of this method for analyzing this kind of material.

In a study conducted by Taparo et al. (2006), in which methods for parasitological analysis used to identify helminth eggs and protozoan oocysts in 
dogs were compared, the Mollay-Willis method and spontaneous sedimentation were the most effective, while the Faust method was the least efficient. In another study conducted by Ross et al. (2011), which verified the prevalence of eggs, larvae, cysts and oocysts of parasites in public squares in the city of Cruz Alta, RS, using the Willis-Mollay, Faust and HPJ methods, 26 positive samples were found among those analyzed with the HPJ method, while the Faust and the Willis-Mollay presented 6 and 4 positive samples, respectively. In the same study, a larger variety of parasitic genera was observed when compared to this study, given that the 34 positive samples $(\mathrm{n}=100)$ contained: Ascaris sp eggs; Ancylostoma sp eggs; Trichuris sp eggs; Dipylidium caninum eggs; Toxoplasma gondii oocysts; Sarcocystis sp oocysts; Giardia sp cysts; Toxocara canis eggs; and Gnathostoma sp eggs. Neves and Massara (2009), using spontaneous sedimentation and the Faust method, observed Toxocara sp, which was not found in this study, and/or cysts of Entamoeba sp (which we also found) in $89.6 \%$ of the samples.

Although recent studies (Cavagnolli et al., 2015; Camello et al., 2016; Rech et al., 2016) have shown that the prevalence of parasitic diseases in children (highest risk group) is not high in our city and nearby municipalities, care must be taken since there are parasites in the soil as shown in this study. Given that these sites are often used for recreational activities and sports, and that people are unaware of the risk they are exposed to, preventive measures should be applied. The large amount of garbage that is often seen on streets, as well as stray animals and feces from these animals, or even from humans, besides other factors, contributing to the transmission of diseases, are a public health issue, as they are directly related to poor hygiene and insufficient education, as well as unhealthy environmental conditions and the population's lack of information (Robertson et al., 2000; Anaruma, 2002; Traub et al., 2004; Pastório et al., 2009).

Hopefully, these results will stimulate the proper offices to take actions regarding decontamination of these places, thus ensuring the health of the population. We also reinforce the importance of pet owners collecting their animals' feces and periodically consulting the veterinarian for treatment. This will avoid inflammation, nutritional, neurological (physical and mental retardation) and cognitive problems, among other consequences of parasitic infections. Control and prevention of zoonotic parasitic diseases avoid public expenditure for future treatments.

\section{REFERENCES}

1. Albino J, Freitas CG, Martins VMS, Kanegusuku H, Roque TP, Bartholomeu T, Forjaz CLM. Tabelas de classificação da aptidão física para frequentadores de parques públicos. Rev Bras Med Esporte 16: 373-377, 2010.

2. Anaruma FF. Toxocaríase humana e parasitoses intestinais em áreas sob o risco de enchentes no município de campinas, estado de São Paulo, Brasil. Campinas: Universidade Estadual de Campinas. Available at: http://www.bibliotecadigital.unicamp.br/ document/?code=vtls0002434682002. Acessed at 20/11/2015. 
3. Camello JT, Cavagnolli NI, Spada PWDS, Poeta J, Rodrigues DR. Prevalência de parasitoses intestinais e condições de saneamento básico das moradias de escolares da zona urbana de Caxias do Sul, Rio Grande do Sul. Scientia Medica, 26: ID21716, 2016.

4. Capuano DM, Rocha GM. Ocorrência de parasitas com potencial zoonótico em fezes de cães coletadas em áreas públicas do município de Ribeirão Preto, SP, Brasil. Rev Bras Epidemiol 9: 81-86, 2006.

5. Capuano DM, Rocha GM. Environmental contamination by Toxocara sp eggs in Ribeirão Preto, São Paulo, Brazil. Rev Inst Med Trop S Paulo 47: 223-226, 2005.

6. Cavagnolli NI, Camello JT, Tesser S, Poeta J, Rodrigues AD. Prevalência de enteroparasitoses e análise socioeconômicas de escolares em Flores da Cunha-RS. Rev Patol Trop 44: 312-322, 2015.

7. Chiodo P. Related factors to human toxocariasis in a rural community of Argentina. Mem Inst Oswaldo Cruz 101: 397-400, 2006.

8. Coelho WMD, Amarante AFT, Apolinário JC, Coelho NMD, Bresciani KDS. Occurrence of Ancylostoma in dogs, cats and public places from Andradina city, São Paulo State, Brazil. Rev Inst Med Trop São Paulo 53: 181-184, 2011.

9. De Carli GA. Parasitologia Clínica: seleção e técnicas de laboratório para o diagnóstico das parasitoses humanas. São Paulo: Atheneu, 2007.

10. Dunn JJ, Columbus ST, Aldeen WE, Davis M, Carroll KC. Trichuris vulpis recovered from a patient with chronic diarrhea and five dogs. J Clinical Microbiol 40: 2703-2704, 2002.

11. Glickman LT, Schantz PM. Epidemiology and pathogenesis of zoonotic toxocariasis. Rev Epidemiol 3: 230-250, 1981.

12. Gawor J, Borecka A, Hanna Z, Zarnowska H, Marczynska M, Dobosz S. Environmental and personal risk factors for toxocariasis in children with diagnosed disease in urban and rural areas of central Poland. Vet Parasitol 155: 217-222, 2008.

13. Labruna MB, Pena HFJ, Souza SLP, Pinter A, Silva JCR, Ragozo AMA, Camargo LMA, Gennaril SM. Prevalência de Endoparasitas em Cães da Área Urbana do Município de Monte Negro, Rondonia. Arq Inst Biol 73: 183-193, 2006.

14. Mascarenhas JP, Silva D. Presença de parasitos no solo das áreas de recreação em escolas de educação infantil. $J$ Nursing and Health 6: 76-82, 2016.

15. Miranda PHS, Lima WF, de Castro TMBQ, Gonçalves, LS. Contaminação do solo de áreas de recreação infantil de creches públicas por Ancylostoma sp. e Toxocara sp. em Teresina-PI. Revista Interdisciplinar 8: 93-98, 2015.

16. Motazedian H, Mehrabani D, Tabatabaee SHR, Pakniat A, Tavali M. Prevalence of helminth ova in soil samples from public places in Shiraz. East Mediterr Health J 12: 562-565, 2006.

17. Neves RLS, Massara CL. Contaminação do Solo de Áreas Comunitárias do Município de Caratinga, MG, Brasil por Ovos de Toxocara sp e cistos de Entamoeba sp. Rev Patol Trop 38: 126-130, 2009.

18. Neves DP, Melo AL, Genaro O, Linardi PM. Parasitologia Humana $11^{\mathrm{a}}$ edição. São Paulo, Livraria Atheneu, 2012.

19. Nunes CM, Pena FC, Negrelli GB, Anjo CGS, Nakano MM, Stobbe NS. Ocorrência de larva migrans na areia de áreas de lazer das escolas municipais de ensino infantil, Araçatuba, SP, Brasil. Rev Saúde Pública 34: 656-658, 2000.

20. Pastório C, Liberati MN, Leonardo JML. Prevalência de parasitas de caráter zoonótico no solo de praças públicas e canis em Maringá, Paraná. In: encontro internacional de produção científica cesumar, Maringá. Anais. Maringa: CESUMAR, 2009.

21. Pessoa SB, Martins AV. Amebas não-patogênicas - amebas de vida livre. In: Pessoa Parasitologia médica. 10 ed. Rio de Janeiro: Guanabara Koogan, 1978. p 253-266. 
22. Pedrazzani ES, Mello DA, Pizzigatti CP, Pripas S, Fucci M, Santoro MCM. Helmintoses Intestinais. III - Programa de Educação e Saúde em Verminose. Rev Saúde Pública 23: 189-195, 1989.

23. Pritsch IC, Frighetto M. Ocorrência de Geohelmintos em Areia de Locais Públicos Municipais de Videira e Itá SC, Brasil. Rev Saúde Pública de Santa Catarina 9: 37-44, 2016.

24. Rech SC, Cavagnolli NI, Spada PWDS, Rodrigues DR. Frequência de enteroparasitas e condições socioeconômicas de escolares da cidade de São Marcos-RS. Semina: Ciências Biológicas e da Saúde 37: 25-32, 2016.

25. Ribeiro LM, Dracz R.M, Mozzer LR, Lima WS. Soil contamination in public squares in Belo Horizonte, Minas Gerais, by canine parasites in different developmental stages. Rev Inst Med Trop São Paulo 55: 229-231, 2013.

26. Robertson ID, Irwin PJ, Lymbery AJ, Thompson RCA. The role of companion animals in the emergence of parasitic zoonoses. Int J Parasitol 30: 1369-1377, 2000.

27. Ross M, Schmitt BAM, De Paula D, Tomazzi RC, Cecchin RS, Kunh F, Tamanho J, Felippin T, Sperotto RL, Zanella JFP. Prevalência de ovos, larvas, cistos e oocistos de parasitas com potencial zoonótico em praças públicas e áreas de lazer na cidade de Cruz Alta - RS. XVI Seminário de Ensino, Pesquisa e Extensão, XVI Mostra de Iniciação Científica, IX Mostra de Estensão da Universidade de Cruz Alta, 2011. Available at: www.unicruz.edu.br/seminario/artigos/saude/ Acessed at 18/11/2015.

28. Santin S. Perspectivas na visão da Corporiedade. In: Moreira, Wagner Wey (ORG); Gebara, Ademir et al. Educação Física e esportes: perspectivas para o século XXI. $5^{\mathrm{a}}$ edição. Campinas, Papirus, 1993. p. 51-69.

29. Santos SA, Merlini LS. Prevalência de enteroparasitoses na população do município de Maria Helena, Paraná. Ciência e Saúde Coletiva 15: 899-905, 2010.

30. Scaini CJ, Toledo RN, Lovatel R, Dionello MA, Gatti FA, Susin L, Signorini VRM. Contaminação ambiental por ovos e larvas de helmintoses fezes de cães na área central do Balneário Cassino, Rio Grande do Sul. Rev Soc Bras Med Trop 36: 617-619, 2003.

31. Schantz PM. Parasitic zoonoses in perspective. Int J Parasitol 21: 161-170, 1991.

32. Silveira ACC, Silva RHA. Os espaços de lazer na cidade: a política urbana de Belo Horizonte. Licere, Belo Horizonte, 13(3): 1-42, 2010. Available at http://www.anima.eefd.ufrj.br/licere/pdf/ licereV13N03_a1.pdf. Acessed at 20/11/2015.

33. Táparo CV, Perri SHV, Serrano ACM, Ishizaki MN, Costa TPDA, Amarante AFT, Bresciani KDS. Comparação entre técnicas coproparasitológicas no diagnóstico de ovos de helmintos e oocistos de protozoários em cães, 2006. Available at http://hdl.handle.net/11449/68706. Acessed at $25 / 11 / 2015$.

34. Traub RJ, Robertson ID, Irwin P, Mencke N, Thompson RCA. The Prevalence, Intensities and risk factors associated with geohelminth infection in tea-growing communities of Assam, India. Trop Med Int Health 9: 699-670, 2004.

35. World Health Organization. 2008. The Global Burden of Disease: 2004 update. Geneva: WHO. Available at http://www.who.int/healthinfo/global_burden_disease/GBD_report_2004update_ full.pdf. Acessed at 20/11/2015.

36. World Health Organization, WHO, 1987. Prevention and Control of Intestinal Parasite Infections. Geneva: World Heath Organization; (Report of WHO, Expert Committee, HO Technical Report Series, 749). Available at http://www.who.int/healthinfo/global_burden_disease/GBD_ report_2004update_full.pdf. Acessed at 20/11/2015. 